Dhaka Univ. J. Biol. Sci. 29(2): 201-208, 2020 (July)

\title{
EFFECTS OF ZINC AND VERMICOMPOST ON THE GROWTH OF SOYBEAN (GLYCINE MAX L.)
}

\author{
T.T. Purna*, A.H.M.Z. Ali and Md. Khalilur Rahman \\ Department of Soil, Water and Environment, University of Dhaka, \\ Dhaka-1000, Bangladesh
}

Key words: Growth, Soybean, Zinc, Vermicompost, Biomass production

\begin{abstract}
A pot experiment was conducted to evaluate the effects of zinc and vermicompost on the growth, yield and nutrient content of soybean (Glycine max L.) plant. The treatment variables were control $(-\mathrm{Zn}$ and $-\mathrm{VC})$, VC 5 ton ha, $\mathrm{Zn} 1$ kg ha, Zn 2 kgha, Zn 3 kghha, Zn 1 kg ha + VC 5 ton/ha, Zn 2 kg ha + VC 5 ton/ha and Zn $3 \mathrm{~kg} / \mathrm{ha}+\mathrm{VC} 5$ ton/ha. Application of zinc and vermicompost showed a significant effect on the growth parameters and macro- and micronutrients uptake by the plant. The highest average plant height $(164 \mathrm{~cm})$, leaf number (80 nos.plant), leaf area (3360 $\mathrm{cm}^{2}$ /plant), fresh weight (49.03 gm/plant), dry weight (24.54 gm/plant), fruit length $(9.4 \mathrm{~cm})$, fruit number per plant (5 nos. plant) were recorded for $\mathrm{Zn} 1 \mathrm{~kg}$ ha $+\mathrm{VC} 5$ ton ha treatment while the lowest values were observed in control at harvest. Results of the growth parameters varied significantly $(\mathrm{p} \leq 0.05)$ with time. It was observed that, the overall best growth performance was achieved in Zn $1 \mathrm{~kg}$ ha + VC 5 ton ha.
\end{abstract}

\section{Introduction}

Soybean (Glycine max L.) is a legume species, widely grown for its edible bean, which has numerous uses. Soybean products, such as textured vegetable protein are ingredients in many meat and dairy substitutes ${ }^{(1)}$. The beans contain significant amount of phytic acid, dietary minerals and B vitamins. The main countries growing soybeans are the United States (32\% of world total) (2016 forecast), Brazil (31\%) and Argentina (18\%). The global production of soybeans is forecasted to be 337 million tons in 2017-2018, The United States, Brazil and Argentina are the world's largest soybean producers and represent more than $80 \%$ of global soybean production ${ }^{(2)}$. In 2016, the average worldwide yield for soybean crops was 2.8 tons per hectare. In Bangladesh, soybean is mainly cultivated in Noakhali and Laxmipur. Also it is now projected to produce soybean in many districts of Bangladesh.

Like some other crops of long domestication, the relationship of the modern soybean to wild-growing species can no longer be traced with any degree of certainty(3). It is a cultural variety with a very large number of cultivars(4). Soybeans grow in distinct

*Author for correspondence: <tasnimtarannum19@gmail.com>. 
morphological stages as they develop from seeds into fully mature plants. Like many legumes, soybeans can fix atmospheric nitrogen by symbiotic bacteria from the Rhizobia group. Together, protein and soybean oil content account for $56 \%$ of dry soybeans by weight (36\% protein and $20 \%$ fat). The remainder consists of $30 \%$ carbohydrates, $9 \%$ water and $5 \%$ ash. Soybeans comprise approximately $8 \%$ seed coat or hull, $90 \%$ cotyledons and $2 \%$ hypocotyl axis or germ ${ }^{(5)}$.

The origin of soybean is reported to be eastern Asia or China. Globally, soybean has ranked first amongst various oilseed crops, contributing approximately $25 \%$ to the world's total oil and fat production. The world's soybean area, production and productivity are 101.81 ha, 253.38 million tones and 2.5 tones ha, respectively. Given normal weather conditions, soybean production is expected to increase 1.96 per cent to 156 thousand MT in 2017/18 (July - Jun). Among oilseeds in Bangladesh, in 2015-2016 soybeans are the fourth crop in terms of total planted area at $9 \%$ of total oilseed planted $\operatorname{area}^{(2)}$.

Soybean has a very good adaptability towards a wide range of soils and climate. It requires an optimum temperature of 26 to $30^{\circ} \mathrm{C}$, the crop does not grow if the temperature falls below $10^{\circ} \mathrm{C}$ and above $40^{\circ} \mathrm{C}$ the growth, flowering and seed formation are affected. It is a short day plant and sensitive to photoperiods. The best type of soil is sandy loam having good organic manure content. Soils with a normal $\mathrm{pH}$ of 7 and a fair degree of water retention capacity are, however, better suited for its cultivation. It is grown on slopes, Jhum land, terraces and plains. It is a potential crop of the region and is grown primarily as a pulse crop as well as intercrop with maize, ragi, arhar etc.

Since no single source is enough to meet the needs of all the plant nutrients, integrated use of all the sources, namely organic manures, fertilizers and bio-fertilizers needs careful attention. Soybean responds well to both organic and inorganic fertilizers. Like other leguminous crops, requirement of nitrogen is substantially fulfilled from symbiotic nitrogen fixation through rhizobium i.e. 125 - $150 \mathrm{~kg} \mathrm{~N} /$ ha is utilized(6) and leaves about $30-40 \mathrm{~kg} \mathrm{~N}$ ha for the succeeding crop. They help in nodule formations in legume crops which in turn fixed atmospheric nitrogen needed for their growth.

A limited number of work has been done on interactions of fertilizers particularly of vermicompost and zinc on growth of soybean. Hence, an experiment was conducted to evaluate the effect of vermicompost and zinc on growth of soybean.

\section{Materials and Methods}

Surface soil sample $(0-15 \mathrm{~cm})$ was collected from Dhamrai, Savar. The sample was air-dried, ground and sieved through $2 \mathrm{~mm}$ sieve. Soil had a pH of 7.54 (1: $2.5 \mathrm{w} / \mathrm{N}$ $\left.\mathrm{H}_{2} \mathrm{O}\right)^{(7)}$, electric conductivity $(49.9 \mathrm{ds} / \mathrm{m})\left(1: 5 \mathrm{w} / \mathrm{H}_{2} \mathrm{O}\right)^{(7)}$, organic carbon $0.156 \%(8)$, organic matter $0.27 \%{ }^{(7)}$, available nitrogen $0.016 \%$ (Kjeldahl extraction)(7), available phosphorus $0.042 \%$ (blue color method using ascorbic acid) ${ }^{(9)}$, exchangeable potassium 
$0.030 \%(10)$, available sulfur $0.0048 \%$ (Turbidimetric method)(11), sand $4.66 \%$, silt $68.33 \%$ and clay $27.01 \%$, textural concentrations of total iron $(2310 \mathrm{mg} / \mathrm{kg})$, manganes $(421$ $\mathrm{mg} / \mathrm{kg})$, zinc $(75 \mathrm{mg} / \mathrm{kg})$ and copper $(26 \mathrm{mg} / \mathrm{kg})$ were determined using an atomic absorption spectrophotometer (VARIAN AA240).
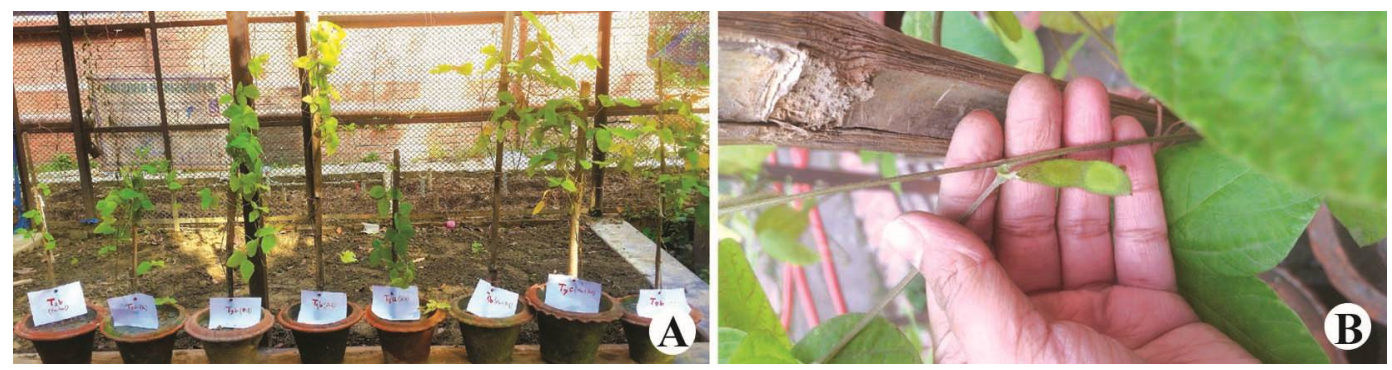

Fig. 1. Glycine max plants: (a) General view of pots, (b) fruit at harvest.

A pot experiment was conducted at the net house of the premises of Department of Soil, Water and Environment, University of Dhaka during Kharif season (Mid-August of 2018 to December of 2018). Seeds (Var. Shohag) were collected from BARI, Joydebpur, Gazipur. This experiment was evaluated in replicated trial with 3 replications and 8 particular treatments. Eight treatments with 3 replications were as follows: Control ( $Z \mathrm{Zn}$ and -VC), VC5 ton ha, Zn 1kg ha, Zn 2 kg ha, Zn 3 kg ha, Zn 1 kg ha + VC 5 ton ha, Zn 2 $\mathrm{kg}$ ha + VC 5 ton ha and Zn $3 \mathrm{~kg}$ ha + VC 5 ton ha. The experiment was conducted by following Completely Randomized Design (CRD). Pots of $10 \mathrm{~kg}$ capacity were taken and marked in accordance with treatment and replication number providing a drainage in the bottom. Eight $\mathrm{kg}$ soil sample was taken in each of the pots. Seed was sown in prepared soil followed by irrigation. Urea, TSP and MP fertilizers was applied in quantities of 20,15 and $30 \mathrm{~kg}$ ha, respectively in each pot as source of N, P and K. Soils were mixed with vermicompost 5 ton ha and zinc sulfate 1,2 and $3 \mathrm{~kg} / \mathrm{ha}$, respectively. Vermicompost was collected from Charfession, Bhola district. Total N, P and K contents of vermicompost were 1.10, 0.29 and $0.82 \%$, respectively. Certified seeds of soybean (Glycine max L.) were collected from 'Quality Seed Company', Siddique Bazar, Dhaka. Three healthy seeds were sown in each pot and water was applied up to field capacity. One healthy seedling was kept in each pot. The pots were watered thrice a week in the morning. The number of leaves, height and leaf area per plant were recorded at 15 days interval up to 120 days. Fruit number and length were measured and recorded during the harvest of soybean at 120 days.

Soybean was harvested after 120 days from the date of germination of seeds. All crops were uprooted and the roots were washed with distilled water to remove any adhering particles on the root surface. The collected plants were separated into different parts like roots, stems, leaves and fruits. The fresh weights of the samples were taken. 
After that the samples were oven dried at $65^{\circ} \mathrm{C}$ for 48 hours that previously packed in envelops and then oven dry weight was taken. The dried samples were then ground separately and preserved in plastic bottles for chemical analysis. LSD test of the results was performed using IBM SPSS, version 25.

\section{Results and Discussion}

Plant growth was observed in terms of plant height (Table 1), leaf number (Table 2), leaf area (Table 3), fresh and dry weight of leaf, stem, root and fruit (Table 4). Height (cm) values of 15, 30, 45, 60, 75, 90, 105 and 120 days increased significantly ( $\mathrm{p} \leq 0.05)$ (Table 1). During the experiment the maximum plant height $(164.0 \mathrm{~cm})$ was observed in $\mathrm{Zn} 1 \mathrm{~kg}$ ha + VC 5 ton ha after 120 days of growth. But a remarkable height was observed in VC 5 ton ha $(156 \mathrm{~cm})$ and $\mathrm{Zn} 2 \mathrm{~kg}$ ha $(150 \mathrm{~cm})$. The minimum plant height $(45 \mathrm{~cm})$ was recorded in control after 120 days of growth. Chemical fertilizer offers nutrients which are readily soluble in soil solution and thereby instantaneously available to plants. Nutrient availability from organic sources is due to microbial action and improved physical condition of soil. Results of this experiment are in agreement with some other workers(14).

Table 1. Plant height $(\mathrm{cm})$ for different dose of $\mathrm{Zn}$ and vermicompost of soybean with continuous interval of days from seed germination to harvest.

\begin{tabular}{lllllllll}
\hline & \multicolumn{7}{c}{ Days after sowing } \\
\cline { 2 - 8 } Treatment & 15 & 30 & 45 & 60 & 75 & 90 & 105 & 120 \\
\hline Control (-Zn and -VC) & 5.4 & 7.3 & 13.0 & 15.3 & 18.6 & 22.8 & 32.0 & 45.0 \\
VC 5 ton/ha & 6.2 & 25.2 & 39.7 & 48.0 & 56.0 & 66.4 & 118.0 & 156.0 \\
Zn 1 kg ha & 6.0 & 38.0 & 41.0 & 45.5 & 53.5 & 63.5 & 96.0 & 128.0 \\
Zn 2 kg ha & 7.8 & 42.0 & 65.6 & 74.0 & 80.0 & 96.5 & 110.0 & 150.0 \\
Zn 3 kg ha & 6.5 & 11.3 & 18.0 & 22.3 & 25.5 & 33.2 & 95.0 & 120.0 \\
Zn 1 kg ha + VC 5 ton/ha & 9.3 & 54.0 & 66.7 & 72.0 & 86.0 & 99.6 & 130.0 & 164.0 \\
Zn 2 kg ha + VC 5 ton/ha & 8.4 & 50.5 & 61.0 & 66.0 & 70.5 & 86.6 & 120.0 & 146.0 \\
Zn 3 kg ha + VC 5 ton/ha & 9.0 & 42.0 & 56.0 & 60.5 & 65.8 & 71.2 & 115.0 & 128.0 \\
LSD at 5\% & 0.092 & 0.183 & 0.139 & 0.214 & 0.242 & 0.277 & 0.282 & 0.237 \\
\hline
\end{tabular}

Number of leaves per plant has a direct bearing effect on the growth of crops. As shown in (Table 2) the number of leaves per plant varied significantly $(\mathrm{p} \leq 0.05)$ and increased with fertilizer dose. Highest number of leaves per plant was produced by $\mathrm{Zn}$ $1 \mathrm{~kg}$ ha $+\mathrm{VC} 5$ ton ha treatment where there was interactive dose of vermicompost and zinc. This is because of the combination of both organic and inorganic fertilizer in suitable dose. The minimum values of leaf number was recorded in control at harvesting. 
It is visible that number of leaves during harvest is higher than the number of leaves at day 15 , this is because the fact that number of leaves were increasing day by day with the length and growth of the plant. Similar findings were reported by others as well(15).

Table 2. Number of leaves counted for different dose of $\mathrm{Zn}$ and vermicompost on soybean with continuous interval of days from seed germination to harvest.

\begin{tabular}{lllllllll}
\hline & \multicolumn{7}{c}{ Days after sowing } \\
\cline { 2 - 8 } Treatments & 15 & 30 & 45 & 60 & 75 & 90 & 105 & 120 \\
\hline Control (-Zn and -VC) & 1 & 4 & 7 & 10 & 15 & 17 & 21 & 30 \\
VC 5 ton/ha & 2 & 11 & 20 & 22 & 30 & 34 & 50 & 78 \\
Zn 1 kg ha & 2 & 9 & 16 & 18 & 25 & 30 & 65 & 75 \\
Zn 2 kg ha & 3 & 11 & 17 & 20 & 28 & 36 & 60 & 67 \\
Zn 3 kg ha & 2 & 5 & 10 & 12 & 18 & 22 & 40 & 56 \\
Zn 1 kg ha + VC 5 ton/ha & 3 & 12 & 18 & 20 & 30 & 34 & 48 & 80 \\
Zn 2 kg ha + VC 5 ton/ha & 3 & 11 & 14 & 16 & 22 & 27 & 62 & 70 \\
Zn 3 kg ha + VC 5 ton/ha & 3 & 20 & 26 & 33 & 42 & 48 & 71 & 76 \\
LSD at 5\% & 0.724 & 1.145 & 1.723 & 1.448 & 1.822 & 2.005 & 1.322 & 2.048 \\
\hline
\end{tabular}

Leaf area is a measure of size of assimilatory system of plant and is a product of leaf length and width. It is also one of the major characteristics influencing plant productivity and is an important determinant of dry matter production and grain yield. Application of fertilizer significantly ( $\mathrm{p} \leq 0.05)$ influenced leaf area of soybean in (Table 3). Data during harvest showed that the highest leaf area $\left(3360 \mathrm{~cm}^{2}\right)$ was recorded in $\mathrm{Zn} 1 \mathrm{~kg}$ ha $+\mathrm{VC} 5$ ton ha. The lowest value of leaf area $\left(408 \mathrm{~cm}^{2}\right)$ was observed in control. It is because of the combined dose of vermicompost and $\mathrm{ZnSO}_{4}$. Result is in agreement with other workers $^{(16)}$.

Fruit number and length are an important yield contributing parameter of soybean. Fruit number and fruit length $(\mathrm{cm})$ were recorded as 1 and 2.1, 3 and 7.0, 2 and 6.5, 2 and 7.1, 1 and 4.6, 5 and 9.4, 4 and 8.3, 2 and 7.7 in the treatments control ( $\mathrm{Zn}$ and $-\mathrm{VC}), \mathrm{VC}$ 5 ton ha, Zn 1 kg ha, Zn 2 kg ha, Zn 3 kg ha, Zn 1 kg ha + VC 5 ton ha, Zn 2 kg ha + VC 5 ton ha and Zn $3 \mathrm{~kg}$ ha + VC 5 ton/ha, respectively. Results of the average fruit number and fruit length per plant of soybean during harvest varied significantly $(\mathrm{p} \leq 0.05)$. The maximum amount of fruit number (5 nos/plant) was observed in $\mathrm{Zn} 1 \mathrm{~kg} / \mathrm{ha}+\mathrm{VC} 5$ ton ha. The second highest value fruit number was (4 nos/plant) was observed in Zn 2 $\mathrm{kg}$ ha + VC 5 ton ha. The minimum number of fruits ( 1 nos/plant) was found in control. The maximum fruit length $(9.4 \mathrm{~cm})$ was observed in $\mathrm{Zn} 1 \mathrm{~kg}$ ha $+\mathrm{VC} 5$ ton ha treatment. The second highest value of fruit length $(8.3 \mathrm{~cm})$ was found in $\mathrm{Zn} 1 \mathrm{~kg}$ ha $+\mathrm{VC} 5$ ton ha. The minimum fruit length was found in control. 
Table 3. Leaf area $\left(\mathrm{cm}^{2}\right)$ for different dose of $\mathrm{Zn}$ and vermicompost on soybean with continuous interval of days from seed germination to harvest.

\begin{tabular}{lllllllll}
\hline & \multicolumn{7}{c}{ Days after sowing } \\
\cline { 2 - 9 } Treatments & 15 & 30 & 45 & 60 & 75 & 90 & 105 & 120 \\
\hline Control (-Zn and - VC) & 3.0 & 23.9 & 47.6 & 73.0 & 142.5 & 187.1 & 252.0 & 408.0 \\
VC 5 ton/ha & 18.0 & 124.3 & 372.0 & 440.4 & 678.0 & 1020.0 & 1247.0 & 2180.0 \\
Zn 1 kg ha & 8.0 & 153.0 & 352.2 & 478.8 & 750.0 & 1055.2 & 1302.0 & 2439.0 \\
Zn 2 kg/ha & 22.2 & 105.6 & 299.2 & 410.0 & 616.6 & 1080.0 & 1346.0 & 2890.0 \\
Zn 3 kg ha & 12.5 & 61.5 & 150.8 & 224.4 & 387.0 & 528.8 & 924.0 & 1830.3 \\
Zn 1 kg/ha + VC 5 ton/ha & 30.0 & 211.2 & 387.0 & 480.0 & 924.0 & 1470.0 & 2064.4 & 3360.0 \\
Zn 2 kg ha + VC 5 ton/ha & 36.9 & 204.6 & 266.4 & 322.2 & 602.2 & 1026.4 & 1724.0 & 2684.7 \\
Zn 3 kg ha + VC 5 ton/ha & 22.4 & 412.2 & 628.0 & 856.0 & 900.0 & 1366.0 & 1964.0 & 3124.0 \\
LSD at 5\% & 1.396 & 0.932 & 1.321 & 1.003 & 0.875 & 3.595 & 0.951 & 1.058 \\
\hline
\end{tabular}

The yields of fresh and dry weights of leaf, stem, root and fruit are presented in (Table 4). The values for leaf, stem, root and fruit varied significantly $(p \leq 0.05)$ for both fresh and dry weights in most of the treatments. The highest yield was obtained due to combined application of organic and inorganic fertilizer which is Zn $1 \mathrm{~kg}$ ha + VC 5 ton ha treatment. The fresh yields were 8.03, 15.55, 17.54 and $6.91 \mathrm{~g} /$ plant and dry weight values were $3.84,7.97,7.98$ and $4.75 \mathrm{~g} /$ plant on day 120 after harvest, respectively. The minimum values for fresh weights were 3.42, 3.61, 4.92 and $0.82 \mathrm{~g} /$ plant and for dry weights were $3.58,3.44,4.26$ and $0.73 \mathrm{~g}$ /plant for leaf, shoot, root and fruit, respectively found in control.

Table 4. Fresh and dry weights for different doses on soybean in root, shoot, leaf and fruit.

\begin{tabular}{|c|c|c|c|c|c|c|c|c|c|c|}
\hline \multirow{2}{*}{ Treatments } & \multicolumn{5}{|c|}{ Fresh weight (g/plant) } & \multicolumn{5}{|c|}{ Dry weight (g/plant) } \\
\hline & Root & Shoot & Leaf & Fruit & Total & Root & Shoot & Leaf & Fruit & Total \\
\hline Control(-Zn and - VC) & 3.42 & 3.61 & 4.92 & 0.82 & 12.77 & 3.58 & 3.44 & 4.26 & 0.73 & 12.01 \\
\hline VC 5 ton $/$ ha & 5.03 & 14.41 & 14.52 & 6.35 & 40.31 & 3.83 & 7.38 & 6.49 & 4.42 & 22.12 \\
\hline $\mathrm{Zn} 1 \mathrm{~kg}$ ha & 6.71 & 17.18 & 19.29 & 3.36 & 46.54 & 4.05 & 8.29 & 7.20 & 2.75 & 22.29 \\
\hline Zn 2 kg ha & 6.26 & 17.64 & 13.40 & 3.48 & 40.78 & 4.02 & 8.22 & 6.16 & 1.98 & 20.38 \\
\hline Zn $3 \mathrm{~kg}$ ha & 4.29 & 7.67 & 9.75 & 1.12 & 22.83 & 3.63 & 4.92 & 4.85 & 0.53 & 13.93 \\
\hline $\mathrm{Zn} 1 \mathrm{~kg}$ ha $+\mathrm{VC} 5$ ton/ha & 8.03 & 15.55 & 17.54 & 6.91 & 49.03 & 3.84 & 7.97 & 7.98 & 4.75 & 24.54 \\
\hline $\mathrm{Zn} 2 \mathrm{~kg}$ ha + VC 5 ton $/$ a & 7.99 & 17.72 & 20.19 & 3.83 & 47.73 & 4.78 & 8.84 & 8.40 & 1.78 & 23.80 \\
\hline $\mathrm{Zn} 3 \mathrm{~kg}$ ha + VC 5 ton/ha & 6.86 & 15.79 & 20.32 & 2.46 & 45.43 & 4.50 & 8.23 & 8.90 & 1.81 & 23.44 \\
\hline LSD at $5 \%$ & 1.368 & 3.961 & 5.235 & 0.681 & - & 0.334 & 1.867 & 1.460 & 0.721 & - \\
\hline
\end{tabular}


The experiment reported here is primarily concerned with the growth response and both fresh and dry matter yield of soybean (Glycine max L.) plants influenced by different treatments of zinc and vermicompost manure. It revealed that different growth parameters have been influenced by the combined application (inorganic + organic) fertilizers. In most of the cases combined application of fertilizers increased the growth parameters, but the treatment $\mathrm{T}_{6}(\mathrm{Zn} 1 \mathrm{~kg}$ ha $+\mathrm{VC} 5)$ has shown the best result than the other treatments where the zinc fertilizers were applied in higher doses. This signifies that the inorganic fertilizers need to be used carefully according to soil health and crop need. If it does, more positive interactive effects of inorganic and organic fertilizers can be possible to get best growth of crops.

\section{References}

1. Mian NR 2006. Applications in Food. CRC Taylor and Francis, Baca Raton. pp. 288.

2. USDA Foreign Agricultural Service, Gain report number BG1802, 2016. http:// gains.fas. usda.gov/Recent\%20GAIN\%20Publications/oilseeds\%20and\%20Products\%20Annual_Dh aka_Bangladesh_3-19-2018.pdf.

3. Shekhar HU, ZH Howlader and Y Kabir 2016. Exploring the Nutrition and Health Benefits of Functional Foods. IGI Global. pp. 223.

4. Raza G, B Mohan, S Prem and L Bhalla 2017. Atanassov, Atanas, ed. In vitro plant regeneration from commercial cultivars of soybean. Bio. Med. Research International. 2017: 7379693. doi:10.1155/2017/7379693.

5. Corke H, C Walker and C Wrigley 2004. Encyclopedia of Grain Science. Academic press.

6. Mark BP and FH David 1990. Nitrogen fixation by legumes in tropical and subtropical agriculture. Adv. Agron. 44: 155-223.

7. Jackson ML 1965. Soil Chemical Analysis. New York, Prentice-Hall Inc. pp. 498.

8. Walkley A and IA Black 1934. An examination of Degtjareff method for determining soil organic matter and a proposed modification of the chromic acid titration method. Soil Sci. 37: 29-37.

9. Olsen SR, CV Cole, FS Watanabe and LA Dean 1954. Estimation of available phosphorus in soils by extraction with sodium bicarbonate.U.S. Dept. Agr. Circ. 939.

10. Pratt PF 1965. Potassium. In: C.A. Black (ed). Methods of Soil Analysis. Part 2. American Society of Agronomy, Inc., Madison, Wisconsin, USA. pp. 1022-1030.

11. Bardsley CE and JD Lancaster 1965. Sulfur. In: C.A. Black (ed). Methods of Soil Analysis. Part 2.American Soc. Agron. Inc., Madison, Wisconsin, USA. pp. 1102-1114.

12. Bouyoucos GJ 1962. Hydrometer method improved for making particle-size analysis of soils. Agron. J. 54: 464-465.

13. Gardner WH 1986. Water content. In: Klute, A. (ed). Methods of Soil Analysis. Part 1. Second Edition, American Soc. Agron. Inc., Soil Sci. Soc. Am. Inc., Madison, Wisconsin, USA. pp. 439-541.

14. Rajeshwari RS, NS Hebsur, HM Pradeep and TD Bharamagoudar 2007. Effect of integrated nutrient management on growth and yield of maize. Karnataka J. Agric. Sci. 20: 399-400. 
15. Robertson MJ 1994. Relationship between internode elongation, plant height and leaf appearance in maize. Field Crops Research 38(3): 135-145.

16. Makinde EA 2007. Effects of an organo-mineral fertilizer application on the growth and yield of maize. J. Applied Sci. Res. 3: 1152-1155.

(Manuscript received on 22 October, 2019; revised on 30 October, 2019) 